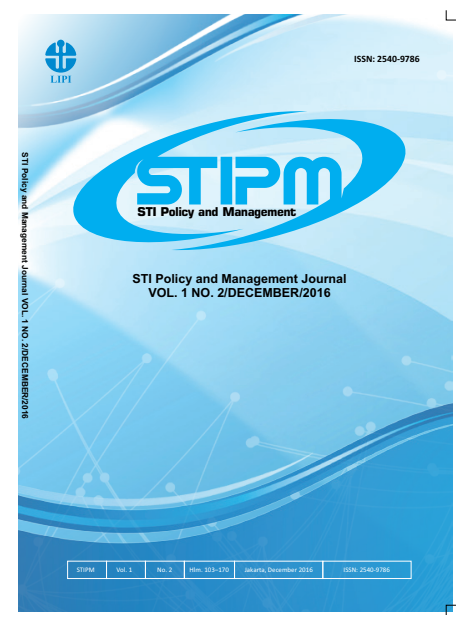

Journal of STI Policy and Management

Publication details, including instructions for authors and subscription information: http://www.stipmjournal.org/

\title{
Effectiveness of Subsidies in Technology Adoption: A Case Study Involving Reverse Osmosis (RO) Membrane Tech- nology
}

\section{Nur Laili, Rendi Febrianda, and Iin Surminah}

Center for Science and Technology Development Studies, Indonesian Institute of Sciences

Version of record first published: 15 December 2016

To cite this article: Laili, N., Febrianda, R. and Surminah, I.. (2016). Effectiveness of Subsidies in Technology Adoption: A Case Study Involving Reverse Osmosis (RO) Membrane Technology. Journal of STI Policy and Management, 1(2), 163-170

To link to this article: http://dx.doi.org/10.14203/STIPM.2016.33

ISSN 2540-9786 (Print); ISSN 2502-5996 (online)

Accreditation Number: 622/AU3/P2MI-LIPI/03/2015

Full terms and conditions of use: https://creativecommons.org/licenses/by-nc-sa/4.0/

You are free to:

- Share : copy and redistribute the material in any medium or format

- Adapt : remix, transform, and build upon the material

- The licensor cannot revoke these freedoms as long as you follow the license terms.

Under the following terms:

Attribution - You must give appropriate credit, provide a link to the license, and indicate if changes were made. You may do so in any reasonable manner, but not in any way that suggests the licensor endorses you or your use.

NonCommercial - You may not use the material for commercial purposes.

ShareAlike - If you remix, transform, or build upon the material, you must distribute your contributions under the same license as the original.

No additional restrictions - You may not apply legal terms or technological measures that legally restrict others from doing anything the license permits.

Notices:

- You do not have to comply with the license for elements of the material in the public domain or where your use is permitted by an applicable exception or limitation.

- No warranties are given. The license may not give you all of the permissions necessary for your intended use. For example, other rights such as publicity, privacy, or moral rights may limit how you use the material.

- If you copy the dataset merely to extract the uncopyrightable data elements would not need permission to do so. However, if you republish the full dataset or using the copyrightable data layers require a permission from PAPPIPTEK-LIPI. 


\section{SCIENCE, TECHNOLOGY AND INNOVATION POLICY AND MANAGEMENT (STIPM) JOURNAL Volume 01, Number 02, December 2016}

\section{FOREWORD by EDITOR-in-CHIEF}

We are very pleased to present the second issue of the Science, Technology and Innovation Policy and Management (STIPM) Journal. We are very excited that the journal has attracted papers from many countries. The variety of paper submissions has supported the international-level initiatives of the journal. Since the beginning of the year, a number of articles have been sent to us. Six articles are published in this issue, while others are still under the first or second phase of review and will follow in the subsequent issue.

In this issue, we present six articles on issues of technology and innovation development and policy at national-, regional-, and firm-level, written by scholars from Australia, Japan and Indonesia. The first article investigates the technological capability of the milk processing industry in Indonesia. The second article investigates mass production of innovation in the business model of start-up companies. The third article explores the diverse effects of four types of mobility on university entrepreneurship. The fourth article explores institutional transformations in local innovation systems used by the farmer community of Belu, East Nusa Tenggara, Indonesia. The fifth article analyzes the transition of bioplastic development in Indonesia, and the last article investigates the effectiveness of subsidies in technology adoption using the case study of reverse osmosis membrane technology in Mandangin Island, East Java, Indonesia. All articles have gone through editorial review by prominent experts.

I would like to thank the authors who have submitted articles to STIPM Journal for their trust, patience and timely revisions as well as for trusting Editor and Editorial Board. I encourage authors to submit their manuscripts. This scientific work is published widely on an open access policy.

My gratitude also goes to all members of the Editorial Board and reviewers who have contributed to this second issue, all of whom increase the quality of articles in this journal even more. We continue to welcome article submissions in the field of science, technology and innovation policy and management.

We wish you a 2017 Happy New Year!

Jakarta, December 2016

Editor-in-Chief 


\section{JOURNAL OF STI POLICY AND MANAGEMENT}

Volume 1, Number 2, December 2016

\section{LIST OF CONTENTS}

How Does the Milk Processing Industry in Indonesia Develop Their Technological Capability?

Budi Triyono, Chichi Shintia Laksani, Muhammad Zulhamdani, and Saut Siahaan $103-116$

Mass producing innovation: a case investigation on why accelerators might not be a paradox

Andrew Barnes

Exploring Diverse Effects of Four Types of Mobility on University Entrepreneurship

SatokoYasuda

Institutional Transformation of Local Innovation Systems in Farmer Community of Belu, East Nusa Tenggara

Febtri Wijayanti, Savitri Dyah, Rachmini Saparita, and Akmadi Abbas

Dynamics of Bioplastics Development in Indonesia

Qinan Maulana B. Soesanto, Dian Prihadyanti, Hartiningsih, and Trina Fizzanty.

Effectiveness of Subsidies in Technology Adoption: A Case Study Involving Reverse Osmosis (RO) Membrane Technology

Nur Laili, Rendi Febrianda, and Iin Surminah 163-170 



\title{
in STI POLICY AND MANAGEMENT \\ LIPI Journal homepage: http://www.stipmjournal.org
}

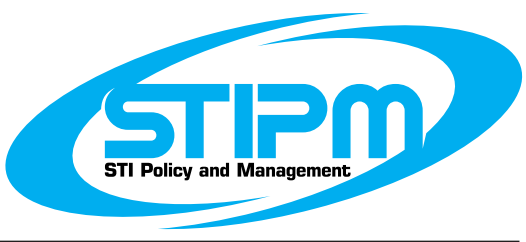

\section{Effectiveness of Subsidies in Technology Adoption: A Case Study Involving Reverse Osmosis (RO) Membrane Technology}

\author{
Nur Laili ${ }^{1}$, Rendi Febrianda, Iin Surminah \\ Center for Science and Technology Development Studies, Indonesian Institute of Sciences
}

\begin{tabular}{|c|c|}
\hline ARTICLE INFO & ABSTRACT \\
\hline $\begin{array}{l}\text { Article History: } \\
\text { Received : } 25 \text { January } 2016 \\
\text { Revised : } 28 \text { November } 2016 \\
\text { Accepted : } 2 \text { December } 2016 \\
\text { Available online : } 15 \text { December } 2016\end{array}$ & $\begin{array}{l}\text { Adoption of new technologies is a process that involves } \\
\text { technological learning and the penetration of new products into } \\
\text { the market. Within the process of new technology adoption, the } \\
\text { government usually intervenes by providing incentives in order } \\
\text { to encourage the success of the adoption. This paper examines }\end{array}$ \\
\hline $\begin{array}{l}\text { Keywords: } \\
\text { Reverse osmosis membrane } \\
\text { Technology adoption } \\
\text { Incentives } \\
\text { Effectiveness } \\
\text { Subsidy } \\
\text { Sustainability }\end{array}$ & $\begin{array}{l}\text { osmosis (RO) membrane technology adoption. It studies the case } \\
\text { of sea water reverse osmosis (SWRO) installation on Mandangin } \\
\text { Island, East Java, Indonesia. Results of the case study identified } \\
\text { government incentives in the form of direct subsidies to decrease } \\
\text { the price of clean water. Although successful in reducing the } \\
\text { price of water, the effectiveness of the subsidies with regard to } \\
\text { the sustainability of SWRO is still low; this is shown by how } \\
\text { the SWRO plant operates only } 30 \% \text { of the full capacity per } \\
\text { year. Further analysis shows that these subsidies are actually } \\
\text { counterproductive to the sustainability of the use of SWRO } \\
\text { technology. Subsidies were able to decrease the price of clean } \\
\text { water, but did not change the buying behavior of the local users. } \\
\text { On the other hand, clean water must be perceived as an economical } \\
\text { goods rather than social goods. }\end{array}$ \\
\hline
\end{tabular}

C2016 PAPPIPTEK-LIPI All rights reserved

\section{INTRODUCTION}

\section{A. Background and Objective}

Policy instruments are the set of techniques by which governmental authorities support and effect or prevent social change (Vedung, 2010). Policymakers can utilize policy instruments as interventions in specific contexts with certain objectives (Segerson, 1999). Policymaker intervention can be carried out directly or indirectly through instruments such as taxes, bonds, loans, rebates and subsidies (Figure 1).

\footnotetext{
* Corresponding Author.

E-mail: nurlaili.lipi@gmail.com
}

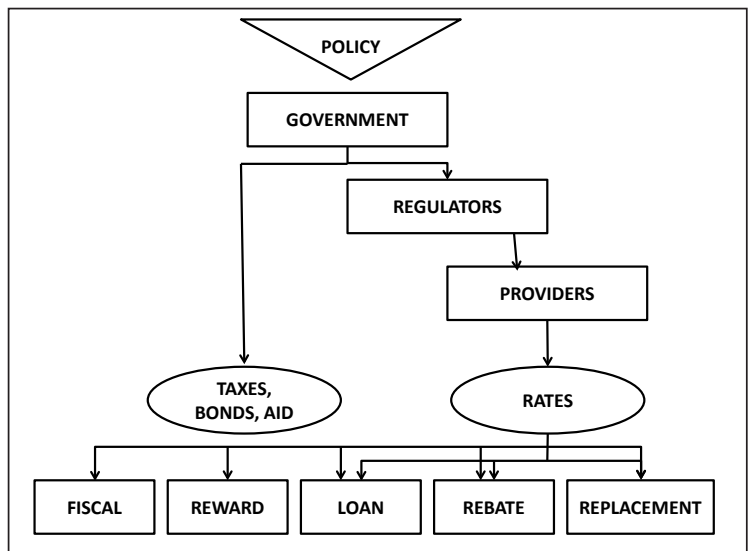

Source: Can, Leventis, Phadke, \& Gopal (2014)

Figure 1. Incentive program policy framework 
The literature shows that policy instruments can be utilised in the context of technology adoption. The government as policymaker may make interventions during a technology adoption process in the form of policy instruments.

Price, as well as long-term investments, becomes crucial in the process of technology adoption (Hazel \& Stanley, 2000). The pricing mechanism is generally strongly influenced by the market where the innovation is to be launched. Price mechanism is a method to calculate and determine price of a product. The effect of pricing mechanisms on the technology adoption process has been widely studied. Literature on pricing mechanisms is largely focused on the potential benefits that can be achieved from the implementation of an effective pricing mechanism for clean water (Garcia \& Reynaud, 2004). In addition, research on the impact of price changes caused by new technology usage was strongly influenced by the level of income and economic ability of users (Sebri, 2014).

In order to support the pricing mechanism in the process of new technology adoption, governments intervene by providing subsidies (Schafer, Hughes, Bryce, \& Richards, 2014). Subsidies may be directly or indirectly given to the new technology adoption process. On the other hand, the government chooses subsidies as a policy instrument for sustainability issues according to their economic, environmental and social effects. A subsidy is a measure that keeps prices for consumers below market levels, keeps prices for producers above market levels, or that otherwise reduces costs for both producers and consumers by giving direct or indirect support (OECD, 2005). Subsidies may be used to correct specific market failures, as generally in the case of certain transport modes and water infrastructure (Cox, 2006).

The implementation of subsidies on technology adoption has been widely discussed in the literature. Aalbers, Heijden, Potters, Soest, and Vollebergh (2009) argue that subsidies for expensive technology can induce technology adoption, although it may be unprofitable. Gilbert and Jones (2015) also find that subsidy programs have effectively supported the adoption of im- proved maize technology in Malawi. Gomez, Salgado, Vasquez, and Chavez (2014) examined four designs of cost-effective subsidy programs, and suggest that an appropriate subsidy program could accelerate technology adoption aimed to reduce environmental effects in Chile. On the other hand, Helveston et al. (2015) find that subsidies have no significant impact on technology adoption, specifically that subsidies could not affect consumers' preferences in buying hybrid electric and battery electric vehicles.

This paper empirically examines the effectiveness of subsidies in technology adoption in the context of a developing country. Reverse osmosis (RO) membrane technology on Mandangin Island, East Java was chosen as the case study, considering the novelty of RO membrane technology implementation for water supplies in Indonesia's coastal areas. Clean freshwater is one of the primary needs for human life, both for industries and households. The availability of clean water in nature can be utilized to meet human demand for clean water. The increasing global demand for water and the limitations from geographical and climate conditions (e.g. El Niño) in many areas mean that the natural stock of clean water often no longer meets the demand of households and industries.

In the past, clean water was usually viewed as a public good where it was provided to the households and industry at zero price and the cost of supplying the water was borne by the government. However, wherever sources of water need to be treated, it is transformed from a public good into an economic good. As an economic good, clean water demands a higher requirement of efficiency and effectiveness in the allocation and utilization of clean water (WMO, 2015). Clean water as an economic good has a price which varies in different markets and countries. The price of clean water in developing countries is relatively high, especially when compared with the price of water in developed countries (Zetland, 2011). In terms of amount, the average use of water in developing countries is much less compared to Europe, Australia, and North America (Keener, Luengo, \& Banerjee, 2010). 
On the other hand, the paradigm shift of clean water from a public good into an economic good involves the application and innovation of technology. The development of water treatment processes for various types of raw water encourages innovation in water treatment technology. As the demand for clean water increased, the need for more treated water also increased, leading to the adoption of new water treatment technology.

Studies on the effect of subsidies on the technology adoption process then become interesting, especially in the field of water supply. Considering the clean water paradigm shift from public good into economic good, the effectiveness the technology adoption process is also impacted by the community culture. The literature shows that research on the effect of subsidies on the process of new technology adoption only focuses on economic aspects and not on the social aspects of clean water traded in the marketplace. In RO membrane adoption, the market plays an important role in water usage and in the water pricing mechanism. The adoption of RO membrane affects the price of clean water, and thus its acceptance is a socio-economic aspect in the process of technology adoption in the field of water supply (Dinar, 2000). An example of this is the community culture, which affect the sustainability of water technology adoption process.

\section{B. Method of Study}

This paper presents a case study of the adoption process of sea water reverse osmosis (SWRO) technology on Mandangin Island, East Java, Indonesia. The case study was conducted through a series of in-depth interviews with actors involved in the SWRO adoption process. The actors included the local government, the SWRO plant construction company, plant operator PDAM Trunojoyo, the community of Mandangin Island, and the financier, the Ministry of Public Works.

The case study was conducted to assess the effect of government subsidies on the adoption of SWRO on Mandangin Island. The SWRO plant provided enough water to fulfill the needs of 1,146 local people. Natural conditions on Mandangin Island caused a limited supply of clean water; the groundwater was brackish and the water source came from rainfall.

The SWRO plant was capable of producing clean water with a capacity of 5 liters per second. The case study showed that the SWRO adoption process could be described by a supply chain which involved several actors with respective roles. As shown in Figure 2, the SWRO adoption process can be divided into three chains: the upstream chain, which was the construction of SWRO plant; the midstream chain, which was the operational processes; and the downstream chain, which directly related to the consumer.

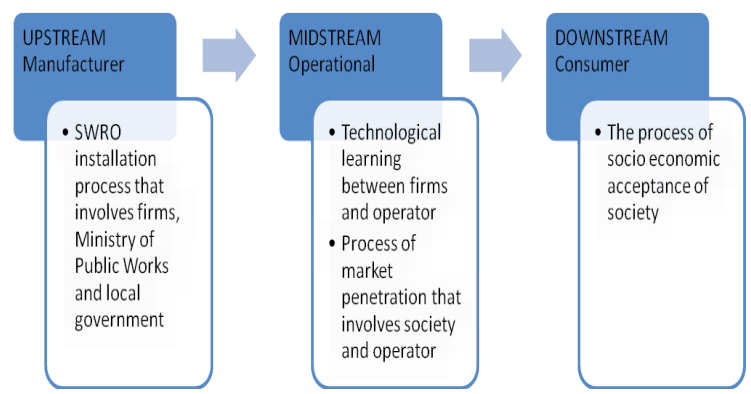

Figure 2. Technology Adoption Process of Reverse Osmosis (RO) Membrane

Technology adoption began with the process of designing and constructing the SWRO plant, which was undertaken by the construction company and funded by the Ministry of Public Works. After the SWRO plant was completed, it was followed by operational processes to produce clean water. The SWRO plant was operated jointly by the construction company and PDAM. Two main aspects of technology adoption occured within the operational processes: first, the transfer of technology from the company to the PDAM, and second, the market penetration process involving operators (company and PDAM) and the user community. The final link in the chain of the technology adoption process was the socioeconomic acceptance of the clean water product by the inhabitants of Mandangin Island.

\section{ANALYTICAL FRAMEWORK}

Adoption of new technology involves two simultaneous processes, namely technological learning by the producer and consumer, and a process of recognition and thus market penetration of a new 
product (Keener et al., 2010). Identification of niche markets and potential consumers is also a necessary step in the adoption of new technology.

In the water treatment industry, the technology and products used in processing will affect two factors: environmental quality and efficiency of processing. Adoption of new technologies in water treatment that aim to improve efficiency of processing is often hampered by a lack of understanding of the complexity of the issues that affect the trials and purchasing decisions (Clark, Jeffrey, \& Stephenson, 2000). Water treatment technology adoption directly affects the level of sustainability of the technology adoption process, especially in the case of SWRO membrane technology.

As a water treatment technology, reverse osmosis membranes are used to treat sea water or brackish water into clean water or drinking water. The decision to adopt reverse osmosis membrane technology is based on the fact that water treatment by reverse osmosis membrane is the most effective and efficient alternative for the provision of clean water in coastal areas in Indonesia (Saha, 2007).

Nevertheless, SWRO has limitations compared to other similar treatments. For example, energy consumption and maintenance costs are relatively high because most of the machinery parts are imported. This limitation raises the production cost of clean water, directly affecting the price of clean water, and has implications on potential government intervention in supporting the process of technology adoption.

Generally, subsidies have two main objectives: market price support and the treatment of uninternalized externalities (Cox, 2006). Uninternalized externalities usually occur in the adoption of new technology, which means cost of new technology production that beyond consumer's ability to pay. In the context of SWRO adoption, direct subsidies have a role as market price support in terms of lowering water prices. Nevertheless, subsidies are often inefficient, expensive and environmentally harmful. These conditions raised the need for approaches to evaluate subsidies' effectiveness. The OECD (2005) identified five main frameworks to subsidy evaluation, as shown in Table 1.
Table 1.

Framework to Subsidy Evaluation

\begin{tabular}{ll}
\hline \multicolumn{1}{c}{ Framework } & \multicolumn{1}{c}{ Objective } \\
\hline Program aggregation & $\begin{array}{l}\text { Adding up the budgetary } \\
\text { transfers of relevant government } \\
\text { programs on national level }\end{array}$ \\
\hline Price-gap & $\begin{array}{l}\text { Evaluate the difference between } \\
\text { the world and domestic market } \\
\text { prices of the product }\end{array}$ \\
\hline Producer-consumer & $\begin{array}{l}\text { Evaluate the budgetary transfers } \\
\text { and price gaps under relevant } \\
\text { support }\end{array}$ \\
& $\begin{array}{l}\text { government programs affecting } \\
\text { production and consumption } \\
\text { alike }\end{array}$ \\
\hline Resource rent & $\begin{array}{l}\text { Evaluate the resource rent } \\
\text { foregone for natural resources }\end{array}$ \\
\hline Marginal social cost & $\begin{array}{l}\text { Evaluate the difference between } \\
\text { the price actually charged and } \\
\text { the marginal social cost }\end{array}$ \\
\hline
\end{tabular}

Source: OECD (2005)

As the research background, this paper utilizes the 'producer-consumer support' framework in evaluating subsidy effectiveness in the Mandangin Island case study.

\section{RESULT}

The case study was conducted through in-depth interviews of the actors involved in each supply chain of technology adoption. The results of the case study were further analyzed to identify government intervention as well as the effectiveness of these interventions in the process of technology adoption.

Results of the qualitative analysis identified an intervention in the form of direct subsidies to the operator of the SWRO plant that aimed to lower the price of clean water. More specifically, the subsidies were given to lower the operational costs of the SWRO plant, so that the selling price was reduced from $\mathrm{Rp} 40,000 / \mathrm{m}^{3}$ to $\mathrm{Rp} 12,500 / \mathrm{m}^{3}$.

Further analysis was undertaken to understand the effect of the subsidies on the SWRO adoption process. The performance of the plant, which operated for three years from 2012 to 2015, was evaluated. The results showed that the plant did not operated continuously. The total achievable annual capacity of operational percentage for SWRO plant was only about 30\% per year. The SWRO plant performance was low due to the capacity not being fully utilized. 
Analysis was also conducted to identify the causes of why the SWRO plant performance only reached $30 \%$ per year. The primary cause of this condition was that the demand for clean water was not continuous throughout the year. For example, demand discontinuity occured in the rainy season, when people ask for the clean water pipe to their homes to be temporarily closed. People prefer rainwater as a source of clean water during the rainy season. Discontinuities in demand was also caused by unwillingness to use clean water produced by the SWRO plant.

Public awareness of the importance of clean water consumption was low. In interviews, consumers of clean water argued that the available brackish water was still suitable for consumption, although it exceeded the threshold for total dissolved solids (TDS) level deemed acceptable by health standards. This belief was based on the perception that people were still healthy despite consuming brackish water. Subsidies granted by the government to lower the selling price of clean water did not encourage consumer behavior to use clean water continuously throughout the year.

Analyses were also conducted on data collected from interviews with the company that constructed the SWRO and PDAM. The SWRO plant has been operating for three years with the support of direct subsidies. The operator argued that the granted subsidies had no significant impact on the sustainability of SWRO adoption. On the other hand, when viewed from the aspect of consumer behaviour, three years of granted subsidies were actually counterproductive to the sustainability of SWRO plant.

The lack of impact was due to two reasons. First, as the operator, PDAM did not have the financial capability to provide subsidies for clean water. Second, a regulation did not allow PDAM, a business unit, to receive subsidies from the local government. Rather, the operator argued that the sustainability of technology adoption was more strongly determined by the market acceptance of clean water. Thus, the sustainability of the technology adoption would be achieved if the plant was fully utilized as an independent business unit, without subsidies.
The effect of subsidies on the process of technology adoption was also analyzed through the results of interviews with RO membrane technology experts involved in the technology adoption. Analysis showed that the effect of the subsidies did not support the sustainability of SWRO adoption process (Figure 3). This was because the supportive effect was only temporary, during the initial phase of the clean water entering the market.

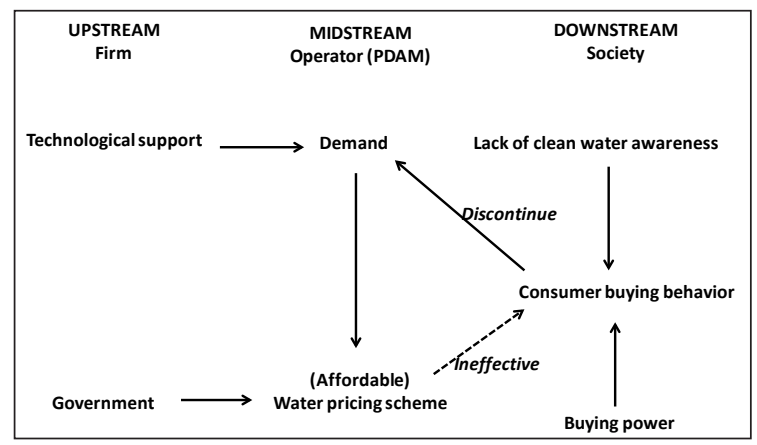

Figure 3. Pricing Mechanism in Technology Adoption Process

The results of the case study showed that the SWRO adoption process was, technically, acceptable. However, economically, the adoption of the technology has not succeeded when viewed from the aspect of market acceptance. This condition indicated that the process of technology adoption was not only determined by the technical aspects, but also determined by the success of such innovation in penetrating the market.

\section{DISCUSSION}

The case study shows that the process of SWRO adoption is supported by government intervention through direct subsidies. Direct subsidies are granted to lower the selling price of clean water. The purpose of these subsidies is to create an affordable price for clean water so that the technology adoption process will be better accepted by local users.

Subsidies in the process of technology adoption can influence consumer purchase decisions, as well as educate the public about the advantages of the products currently adopted (Can, Leventis, Phadke, \& Gopal, 2014). However, the findings of the case study in the Mandangin Island are 
not fully in line with this argument, especially as subsidies do not encourage local users to use clean water continuously throughout the year. Discontinued demand is caused by the behaviour of local users in buying clean water. The granted subsidies are able to decrease the price of clean water, but do not change the buying behavior of the local users. Thus, this finding is in line with the argument that direct subsidies on the price of clean water is not effective if people have low incomes (Whittington, Nauges, Fuente, \& Wu, 2015). As found by this case study, local users are low-income earners, showing that the price decrease do not directly affect the demand for clean water.

The case study shows that, to be sustainable, the SWRO plant must be managed as an independent business unit without subsidies. Subsidies can be given, but only in the stage where the products are introduced to the market, and within a limited time period. These findings support the argument that the use of financial incentives such as subsidies are only effective for a limited time (Gold \& Nadel, 2011). This finding is also in line with the argument that a pricing mechanism based on full-cost pricing (without subsidies) will show the real market value of clean water (Arpke \& Strong, 2006). For the SWRO plant manager, a full-cost pricing would be able to provide a picture of the actual financial risk of technology adoption.

Further analysis is conducted through comparisons between the results of the case study with several other subsidy implementation experiences in several countries. In 1996, New Zealand removed subsidies from the agricultural sector due to the environmentally harmful effect of the subsidies (Vitalis, 2006). In 1995, Australia's policies regarding water supplies moved away from government subsidisation towards allowing the creation of water markets and more effective pricing policies (Pittar, 2006). A similar shift also occurred in Norway when the government removed several subsidies from the fisheries sector (Hannesson, 2006). The removal of subsidies from Norway's fisheries sector enabled the industry to survive on its own. On the other hand, we also find successful experiences of subsidy implementation. In Florida, USA, flexible subsidies for farmer are able to provide long-term water quality improvement to restore the ecosystem (Lee \& Milon, 1999). Casey and Lynne (1999) also found that subsidies were generally able to enhance the adoption of waterconserving technology in the agriculture sector.

In the case study, subsidies proved counterproductive to the adoption of SWRO. These findings imply that there is potential for other forms of government intervention to have better chances of supporting the sustainability of SWRO adoption; therefore, there is a need to create a more proactive policy based on investment. From the comparative study above, the following conclusions can be made. First, temporary subsidies without a proper framework tend to fail to achieve its objectives. Second, the removal of subsidies would enable the industry to survive on its own, specifically in market creation. Third, better management and a flexible subsidy framework can enhance the chances of success in subsidy implementation.

\section{CONCLUSION}

SWRO adoption on Mandangin Island occurred began with the construction of a SWRO plant to produce clean water. The results of this case study showed that the government gave a direct financial incentive in the form of subsidies towards the technology adoption in order to decrease the price of the produced clean water.

However, the effectiveness of the subsidies did not affect the sustainability of SWRO technology, as the plant operated for only $30 \%$ of the full capacity per year. The low operation of the SWRO plant was related to the behavior of local users, among whom awareness for the use of clean water is still low.

\section{ACKNOWLEDGEMENT}

This article was presented in $12^{\text {th }}$ ASIALICS in Yogyakarta, Indonesia. The authors would like to thank Mr. M. Kusbiantono for supporting the research process. 


\section{REFERENCES}

Aalbers, R., Heijden, E. V. D., Potters, J., Soest, D. V, \& Vollebergh, H. (2009). Technology adoption subsidies: An experiment with managers. Energy Economics, 31, 431-442.

Arpke, A., \& Strong, K. (2006). A comparison of life cycle cost analyses for a typical college dormitory using subsidized versus full-cost pricing of water. Ecological Economic, 58, 66-78.

Can, S., Leventis, G., Phadke, A., \& Gopal, A. (2014). Design of incentive programs for accelerating penetration of energy-efficient appliances. Energy Policy, 72, 56-66. (http:// dx.doi.org/10.1016/j.enpol.2014.04.035)

Casey, F., \& Lynne, G. D. (1999). Adoption of water conserving technologies in agriculture: The role of expected profiles and public interest. In $F$. Casey, A. Schmitz, S. Zwinton, \& D. Zilberman (Eds.), Flexible incentives for the adoption of environmental technologies and agriculture. New York: Springer Science Business Media.

Clark, T., Jeffrey, P., \& Stephenson, T. (2000). Complex agendas for new technology adoption in the UK water industry. Technovation, 20, 247-256.

Cox, A. (2006). Overview of approaches for assesing subsidies. In OECD, Subsidy reform and sustainable development: economic, environmental and social aspects. OECD Sustainable Development Studies: OECD Publishing.

Dinar, A. (2000). The political economy of water pricing reforms. UK: Oxford University Press.

Garcia, S., \& Reynaud, A. (2004). Estimating the benefits of efficient water pricing in France. Resources Energy Economy, 26, 1-25.

Gilbert, J. R., \& Jones, M. (2015). Does storage technology affect adoption of improved maize varieties in Africa? Insights from Malawi's input subsidy program. Food Policy, 50, 92-105. (http://dx.doi.org/10.1016/j.foodpol.2014.10.015)

Gold, R., \& Nadel, S. (2011). Energy efficiency tax incentive, 2005-2011: How have they performed? NY: American Council for an Energy Efficient Economy White Paper.

Gomez, W., Salgado, H., Vasquez, F., \& Chavez, C. (2014). Using stated preference methods to design cost-effective subsidy programs to induce technology adoption: An application to a stove program in Southern Chile. Journal of Environmental Management, 132, 346-357. (http://dx.doi.org/10.1016/j.jenvman.2013.11.020)
Hazell, P., \& Stanley, W. (2000). From science to technology adoption: The role of policy research in improving natural resource management. Agriculture, Ecosystem and Environment, 82, 385-393.

Helveston, J. P., Liu, Y., Feit, E. M., Fuchs, E., Klampfl, E., \& Michalek, J. J. (2015). Will subsidies drive electric vehicle adoption? Measuring consumer preferences in the U.S. and China. Transportation Research Part A, 73, 96-112. (http://dx.doi.org/10.1016/j.tra.2015.01.002)

Hannesson, R. (2006). Subsidy reform in the Norwegian fisheries sector. In OECD, Subsidy reform and sustainable development: Economic, environmental and social aspects. OECD Sustainable Development Studies: OECD Publishing.

Keener, S., Luengo, M., \& Banerjee, S. (2010). Provision of water to the poor in Africa: Experience with water standposts and the informal water sector. USA: The World Bank.

Lee, D. J., \& Milon, J. W. (1999). Flexible incentives and water quality control technologies. In $F$. Casey, A. Schmitz, S. Zwinton, \& D. Zilberman (Eds.) Flexible incentivew for the adoption of environmental technologies and agriculture. New York: Springer Science Business Media.

OECD. (2005). Environmentally harmful subsidies: Challenge for reform. Paris: OECD Publishing.

Pittar, R. (2006). Water reform and the agricultural sector in Australia. In OECD, Subsidy Reform and Sustainable Development: Economic, Environmental and Social Aspects. OECD Sustainable Development Studies: OECD Publishing.

Saha, S. (2007). Consumer preferences and product and process R\&D. The RAND Journal of Economics, 38(1), 250-268.

Schafer, A. I., Hughes, G., Bryce, S., \& Richards S. (2014). Renewable energy powered membrane technology: A leapfrog approach to rural water treatment in developing countries. Renewable and Sustainable Energy Reviews, 40, 542-556. (http://dx.doi.org/10.1016/j.rser.2014.07.164)

Sebri, M. (2014). A meta-analysis of residential water demand studies. Environment Development Sustainability, 16(3), 499-520. (http://dx.doi. org/10.1007/s10668-013-9490-9)

Segerson, K. (1999). Flexible incentives: A unifying framework for policy analysis. In F. Casey, A. Schmitz, S. Zwinton, \& D. Zilberman (Eds.) Flexible incentives for the adoption of environmental technologies in agriculture. New York: Springer Science Business Media. 
Vedung, E. (2010). Policy instruments: Typologies and theories. In M. Bemelmans-Videc, R.C Rist \& E Vedung (Eds.), Carrots, sticks and sermons, policy instrument and their evaluations. New Brunswick and London: Transaction Publishers.

Vitalis, V. (2006). Subsidy reform in the New Zealand agricultural sector. In OECD, Subsidy reform and sustainable development: economic, environmental and social aspects. OECD Sustainable Development Studies: OECD Publishing.

Whittington, D., Nauges, C., Fuente, D., \& Wu, X. (2015). A diagnostic tool for estimating the incidence of subsidies delivered by water utilities in low- and medium-income countries, with illustrative simulations. Utilities Policy, 34, 70-81. (http://dx.doi.org/10.1016/j. jup.2014.12.007)
World Meteorological Organization (WMO). (2015). The Dublin Statement on sustainable development. Retrieved 20 June 2015 from https:// www.wmo.int/pages/prog/hwrp/documents/ english/icwedece.html.

Zetland, D. (2011). Global water tariffs continue upward trend. Global Water Intell, 12(9). Retrieved June 14 ${ }^{\text {th }}, 2015$ from https:// www.globalwaterintel.com/global-waterintelligence-magazine/12/9/market-profile/ global-water-tariffs-continue-upward-trend/. 